\title{
Class Program Differences in Student's Scientific Literacy
}

\author{
Noly Shofiyah \\ Fakultas Keguruan dan Ilmu Pendidikan \\ Universitas Muhammadiyah Sidoarjo \\ Sidoarjo, Indonesia \\ nolyshofiyah@umsida.ac.id
}

\author{
Amar Abdillah \\ Fakultas Keguruan dan Ilmu Pendidikan \\ Universitas Muhammadiyah Sidoarjo \\ Sidoarjo, Indonesia \\ amarabdillah78@gmail.com
}

\begin{abstract}
Currently, scientific literacy became one of the learning outcomes of science education. Through scientific literacy skills, students can overcame any problems of science. This study aimed to describe the student's scientific literacy skills based on program classes. Two groups were identified, namely regular eighth-grade students and students who finished school for 2 years only. The scientific literacy tests were adapted from The PanCanadian Assessment Program (PCAP) of 2013 because the students were on grade 8 . The data were collected by using tests, interviews and observations. The findings indicated that the students in the accelerated class had the scientific reasoning and the problem solving ability of the scientific literacy. Meanwhile the students who were in the regular class mastered the scientific literacy skills in term of scientific reasoning. The results of this study can be used as a reasoning by the teacher, researcher, and decision makers that the scientific literacy abilities of students still need to be improved.
\end{abstract}

Keywords—scientific literacy skills; class program; Bybee scale

\section{INTRODUCTION}

Science is learned so that students not only understand the contents but also can apply the concepts to solve daily problems. The main goal of science learning is the realization of students who have scientific literacy skills [1]. Therefore, to develop scientific literacy of students, it is required innovative efforts in improving the quality of education in Indonesia. The implementation of accelereted class, in which students can complete their educational programs more quickly than regular programs, is one of the inventive ways to improve the quality of education in Indonesia [2]. Hence, students can select the class program based on their abilities, talents, and interests.

The students who have more interest and cognitive abilities than others can develop their potential by attending an acceleration class. They have differences in needs above the students in their age. The students in the accelerated program are students who have Intelligence Quality (IQ) of at least 110, and Task Commitment (TC) and Creativity Quatiens (CQ) above others. Meanwhile, the students of regular class are students who have average ability and comply the subject according to the curriculum structure [3].

Many researchers define scientific literacy as the ability to conceptualize the scientific issues [4], to construct arguments and ideas of science in the scientific group of discussion [5], and to analyze data and interpret evidence [6]. Students became scientifically literate when they have ability to identifiy questions, explain scientific phenomena and draw conclusion of science issues by using their scientific knowledge [7]. Council of Minister of Education Canada (CMEC) reveal that scientific literacy is a student's competence in understanding the nature of science including attitudes, skills, and knowledge to conduct inquiries, to solve problems, and to reason scientifically [8]. Currently, scientific literacy has been interpreted not only as the ability to read and comprehend science-related articles but also the capability to understand and apply scientific principles to everyday life [9]. In this study, scientific literacy refers to three competences, such as scientific investigation, problem solving, and scientific reasoning.

Some previous research of scientific literacy were about the identification of the level of scientific literacy of science students either at junior nor university level [10] [11] [12]. These studies divide the scientific literacy into four levels that are nominal, functional, procedural, and multidimensional [12]. Scientific literacy is considered necessary to be examined because in Indonesia the issue is still relatively new. Moreover, if the scientific literacy is identified based on the difference of the class program in which the students in each program have different intelligence capabilities.

\section{METHOD}

This study was a qualitative research with phenomenological approach. Subject selection in qualitative research is purposeful [13]. So that, this research was conducted in SMP Negeri 3 Sidoarjo (Junior High School in Sidoarjo) which is one of acceleration education organizer and culture literacy development school. Participants are selected who can best inform the research questions and enhance understanding of the phenomenon under study [13]. The participant used in this study are a student of the accelerated class and a students of regular class in which both of them 
have the same age and cognitive ability. To get the same cognitive ability, firstly, the students are examined by the test. The students who got the same score and age then selected as a participant.

The data of scientific literacy are collected using tests, interviews, and observations. Firstly, the scientific literacy test consisting of scientific inquiry, problem solving and scientific reasoning were administered to students. The results are then categorized in the scientific literacy of Bybee's scale. The scientific literacy test is prepared based on the questions of PCAP 2013 consisting of 6 items translated into Indonesian and validated by two experts of science education. Problem 3 and 4 measured scientific investigation competencies, problem 2 and 5 identified problem-solving competencies and problem 1 and 6 assessed the competence of scientific reasoning.

The second way was observation. Observation was conducted while the students performed the scientific literacy test to investigate the ability directly. Finally, students are interviewed about science issues. Interviews were conducted in order to obtain rational data of scientific literacy so as to strengthen the results of tests and observations [14]. All of the data were then analyzed using qualitative data analysis of Miles and Huberman's Model, namely reduction, data presentation and conclusion. At the end, the data are validated by technique triangulation.

\section{RESEARCH FINDINGS AND DISCUSSION}

\section{A. Scientific Literacy of Scientific Inquiry}

Scientific inquiry requires students to address or develop questions about the nature of things that involves extensive exploration as well as focused investigations. In this research, the competence of scientific inquiry is in question 3 and 4.

Question number 3 focuses on the competence of scientific inquiry. As a step to answer this question appropriately, students must have sufficient understanding of the scientific method so that students are able to identify a statement whether or not to be scientifically investigated.

Question number 4 centers on the competence of scientific inquiry. This question asks students to draw conclusions based on experimental evidence observed. This question requires students to identify variables that change and then communicate in general about the relationship between the variables. In addition students should have sufficient understanding of the inquiry method to recognize the required measurements when setting up this experiment.

The following table 1 showed the student's skill of scientific inquiry in the acceleration and regular class. In this skill, both students in accelerated and regular class did not yet have scientific inquiry skills.
TABLE 1 STUDENT'S SKILL OF SCIENTIFIC INQUIRY IN THE ACCLERATION AND REGULAR CLASS

\begin{tabular}{|c|c|c|}
\hline $\begin{array}{c}\text { Technique } 1 \\
\text { (Test) }\end{array}$ & $\begin{array}{c}\text { Technique } 2 \\
\text { (Observation) }\end{array}$ & $\begin{array}{c}\text { Technique } 3 \\
\text { (Interview) }\end{array}$ \\
\hline \multicolumn{3}{|c|}{ Acceleration Class } \\
\hline $\begin{array}{l}\text { Question no } 3 \\
\text { Student in this class } \\
\text { program could not } \\
\text { answer the problem } \\
\text { correctly } \\
\text { Question no } 4 \\
\text { Student is able to } \\
\text { answer the question } \\
\text { correctly. }\end{array}$ & $\begin{array}{l}\text { In the observation, } \\
\text { student appeared to } \\
\text { lack the competence of } \\
\text { scientific inquiry. } \\
\text { Student was only seen } \\
\text { mastering one of the } \\
\text { three sub-indicators of } \\
\text { scientific inquiry. }\end{array}$ & $\begin{array}{l}\text { The interview result } \\
\text { provided information } \\
\text { that student of } \\
\text { accelerated class } \\
\text { program had difficulty } \\
\text { in answering question } \\
\text { no } 3 \text {, but at question } \\
\text { no } 4 \text {, student stated } \\
\text { easy and the problem } \\
\text { have been studied }\end{array}$ \\
\hline \multicolumn{3}{|c|}{ Regular Class } \\
\hline $\begin{array}{l}\text { Question no } 3 \\
\text { The student of } \\
\text { regular class } \\
\text { program cannot } \\
\text { answer the question } \\
\text { correctly } \\
\text { Question no } 4 \\
\text { Regular classroom } \\
\text { students can answer } \\
\text { less precisely }\end{array}$ & $\begin{array}{l}\text { The results of } \\
\text { observation indicate } \\
\text { that the students of } \\
\text { regular class program } \\
\text { have not yet got the } \\
\text { competence of } \\
\text { scientific } \\
\text { investigation. }\end{array}$ & $\begin{array}{l}\text { Interview results } \\
\text { obtained information } \\
\text { that the student of } \\
\text { regular class program } \\
\text { have difficulty in } \\
\text { answering questions } \\
\text { no } 3 \text { and } 4\end{array}$ \\
\hline
\end{tabular}

\section{B. Scientific Literacy of Problem Solving}

In the problem solving, students are required to find answers to practical problems requiring the application of their science knowledge in new way. Students demonstrate this competency by applying their knowledge of science, their skills, and their understanding of the nature of science to solve science-related problems. The skill of problem solving is in question 2 and 5.

Question number 2 required student to seek answers to practical problems that require the application of existing knowledge to students. Student was asked to make two considerations that he will do to keep the organism alive when under the class. To answer correctly, student must state the way in relation to place, air or food.

In the question number 5, the student was asked to indicate whether a suggestion will be able to reduce the use of bottled water. As a step to answer question 5 correctly, students must have the ability to choose the right solution in relation to the identified problem.

The table below presented the the student's competence of problem solving in the acceleration and regular class.

TABLE 2 STUDENT'S SKILL OF PROBLEM SOLVING IN THE ACCLERATION AND REGULAR CLASS

\begin{tabular}{|c|c|c|}
\hline $\begin{array}{c}\text { Technique } 1 \\
\text { (Test) }\end{array}$ & $\begin{array}{c}\text { Technique } 2 \\
\text { (Observation) }\end{array}$ & $\begin{array}{c}\text { Technique } 3 \\
\text { (Interview) } \\
\end{array}$ \\
\hline \multicolumn{3}{|c|}{ Acceleration Class } \\
\hline $\begin{array}{l}\text { Question no } 2 \\
\text { The student can answer } \\
\text { the question correctly. } \\
\text { Question no } 5 \\
\text { The student answers } 3 \\
\text { statements correctly and } \\
\text { a statement is answered } \\
\text { incorrectly }\end{array}$ & $\begin{array}{l}\text { The results of the } \\
\text { observations on the } \\
\text { questions } 2 \text { and } 5 \\
\text { show that the students } \\
\text { of the acceleration } \\
\text { class program have } \\
\text { problem-solving } \\
\text { competencies }\end{array}$ & $\begin{array}{l}\text { From the interviews, } \\
\text { it was found that the } \\
\text { students of the } \\
\text { acceleration class } \\
\text { program stated that the } \\
\text { question was easy, } \\
\text { workable and had been } \\
\text { studied. }\end{array}$ \\
\hline
\end{tabular}


ONT.

\begin{tabular}{|l|l|l|}
\hline \multicolumn{1}{|c|}{$\begin{array}{c}\text { Technique 1 } \\
\text { (Test) }\end{array}$} & \multicolumn{1}{c|}{$\begin{array}{c}\text { Technique 2 } \\
\text { (Observation) }\end{array}$} & \multicolumn{1}{c|}{$\begin{array}{c}\text { Technique 3 } \\
\text { (Interview) }\end{array}$} \\
\hline \multicolumn{3}{|c|}{ Regular Class } \\
\hline $\begin{array}{l}\text { For questions 2 and 5, } \\
\text { student of regular class } \\
\text { answered }\end{array}$ these & $\begin{array}{l}\text { The results of } \\
\text { observations } \\
\text { questions 2 and 5 } \\
\text { questions } \\
\text { inappropriately that student of } \\
\text { regular class did not } \\
\text { yet have problem } \\
\text { solving competencies }\end{array}$ & $\begin{array}{l}\text { The results of the } \\
\text { interviews indicate } \\
\text { that student in the } \\
\text { regular class program } \\
\text { claimed that He/She } \\
\text { had never done such a } \\
\text { thing before }\end{array}$ \\
\hline
\end{tabular}

In this competency, the student in accelerated class is more masterfull than the student in regular class. In other words, student of acceleration class have problem solving skills, whereas student of regular class did not.

\section{Scientific Literacy of Scientific Reasoning}

This competence required students are being able to reason scientifically and make connections by applying scientific knowledge and skills to make decisions and address issues involving science, technology, society, and the environment. Scientific reasoning involves a comparison, rationalization, or reasoning from the student in relation to an existing theory or frame of reference. Students demonstrate this competency by applying their knowledge of science, their skills, and their understanding of the nature of science to make informed, evidence-based decisions.

The competence of scientific reasoning is in questions 1 and 6, which will be described as follows: Question number 1 required students to predict the way an organism takes food based on the presented image. Meanwhile, question number 6 requires students to make opinions about the replacement of plastic bottles with glass bottles.

The following table 3 was about the student's competence of scientific reasoning either in acceleration class or regular class.

TABLE 3 StUdent's SKILl of SCIENTIFIC REASONING IN THE ACCELERATION AND REGULAR CLASS

\begin{tabular}{|c|c|c|}
\hline $\begin{array}{l}\text { Technique } 1 \\
\text { (Test) }\end{array}$ & $\begin{array}{c}\text { Technique } 2 \\
\text { (Observation) }\end{array}$ & $\begin{array}{l}\text { Technique } 3 \\
\text { (Interview) }\end{array}$ \\
\hline \multicolumn{3}{|c|}{ Acceleration Class } \\
\hline $\begin{array}{l}\text { Question no } 1 \\
\text { Students can } \\
\text { respond } \\
\text { appropriately } \\
\text { Question no } 6 \\
\text { Students also could } \\
\text { answer correctly }\end{array}$ & $\begin{array}{l}\text { The results of } \\
\text { observation indicate } \\
\text { that the student has } \\
\text { scientific reasoning } \\
\text { competence. }\end{array}$ & $\begin{array}{l}\text { From the interview, } \\
\text { students stated that } \\
\text { "this question is better } \\
\text { because it asks us } \\
\text { about the suggestion, } \\
\text { the matter is simple } \\
\text { and easy" }\end{array}$ \\
\hline \multicolumn{3}{|c|}{ Regular Class } \\
\hline $\begin{array}{l}\text { Question no } 1 \\
\text { Student of regular } \\
\text { class can respond } \\
\text { the question no } 1 \\
\text { appropriately } \\
\text { Question no } 6 \\
\text { Student of regular } \\
\text { class respond the } \\
\text { problem no } 6 \\
\text { appropriately }\end{array}$ & $\begin{array}{l}\text { The results of the } \\
\text { observation indicate } \\
\text { that the student of the } \\
\text { regular class program } \\
\text { have the competence } \\
\text { of scientific reasoning }\end{array}$ & $\begin{array}{l}\text { At the time of the } \\
\text { interview, the student } \\
\text { of the regular class } \\
\text { program said He/She } \\
\text { understood and could } \\
\text { do it even though they } \\
\text { had never done such a } \\
\text { thing before. }\end{array}$ \\
\hline
\end{tabular}

Scientific reasoning is the only scienctific literacy skill that was mastered by both students in the acceleration class and regular class.

\section{Discussion}

This part will discuss the findings research in relation to certain standard and relevant literatures. The studentsachievments of scientific literacy competences, are presented in the table 4.

TABEL 4 SCIENTIFIC LiteraCy BASED ON Class PROGRAM

\begin{tabular}{|l|c|c|c|}
\hline \multirow{2}{*}{\begin{tabular}{c}
\multirow{2}{*}{$\begin{array}{c}\text { Class } \\
\text { Program }\end{array}$} \\
\cline { 2 - 4 }
\end{tabular}} & \multicolumn{3}{|c|}{ Competences } \\
\hline $\begin{array}{l}\text { Accelerated } \\
\text { class } \\
\text { (4 semester) }\end{array}$ & $\mathrm{X}$ & $\begin{array}{c}\text { Problem } \\
\text { Solving }\end{array}$ & $\begin{array}{c}\text { Scientific } \\
\text { Reasoning }\end{array}$ \\
\hline $\begin{array}{l}\text { Regular class } \\
\text { (6 semester) }\end{array}$ & $\mathrm{X}$ & $\sqrt{ }$ & $\sqrt{ }$ \\
\hline
\end{tabular}

Based on the table I, it is known that students who attend different class programs (both acceleration and regular) already have the competence of scientific literacy in the category of scientific reasoning, but in different levels. Based on the scientific literacy scale Bybee, students who attend the acceleration class program included in the functional level. In other words, students can clarify the concept correctly, but have a limited understanding. Students are able to recall information from textbooks like writing basic facts, but not being able to justify their own opinions based on a given text or graph. Students even know the concept of interdiscipline, but are unable to describe the relationship between the concepts.

Meanwhile, students who take the regular class program, are in nominal level in the term of scientific reasoning. In the students answer, it appears that the students agree with what the other person expressed in the absence of their own ideas. Students write and use the scientific terms, but they are unable to justify the term or misconception.

Furthermore, in the term of problem solving of scientific literacy skill, students who are in the accelerated class program have the competence, but the students of the regular class program do not have a such competency yet. The problem solving aspect is important to be considered and applied by the teacher in the learning of science, because the principle of learning science is a process of student interaction with the environment to solve scientific problems. Based on the scale of Bybee'sscienctific literacy, the students of the accelerated class program are in the functional level.

The competency of scientific inquiry is the only of the three competences of scientific literacy that have not been mastered by students either in the acceleration or regular program. It means that the students still do not have all the competences of scientific literacy.

The reason is because the custom of teaching science in schools emphasize on the cognitive aspect rather than develop students' higher order thinking skills. In addition, students are not yet accustomed to finish tests or problems related to the 
science process skills that are a major part of scientific literacy. The lack of students' ability in formulating variables, designing experiments, and communicating experiments in writing is because the learning science in their previous schools has not been implemented in accordance with the nature of science [10].

Another possible cause is that the textbook used. Science textbooks should contain aspects of scientific literacy so that students are literate of science. The previous study identify that the nine books of science in junior high school, have reflected the scientific literacy, but the proportion of the emergence of scientific literacy categories is not balanced. The category that looks dominant is science knowledge [15].

In the curriculum, learning science has directed students to develop scientific literacy. Science lessons in junior high school are competency-based learning, in which the competency requires students to master the concept of science through the science process, such as experimental methods. In addition, schools have encouraged the students to prefer reading through "school literacy programs". One of the program activities is to create a mind mapping related to the books that students read. The implementation of mind mapping in teaching science has been successfully assisting students to enhance their scientific literacy skill [16]. The most significant improvement occurs in the domain of explaining the phenomenon scientifically.

Finally, training students with scientific literacy-oriented questions, such as scientific reasoning, problem solving, and scientific inquiry, should be included in the "school literacy programs". The school has to require the teachers explicitly trains the scientific method or process to their students, so that they are habituated to do activities such as: scientific reasoning, problem solving and scientific investigation. The learning cycle model is recommended by the previous researchers as an alternative teaching model to train scientific literacy skills [17]. Using effective educational strategies, such as inquiry, project based learning can encourage creativity and innovation, and builds trends of scientific literacy [18] [19].

\section{IV.CONCLUSION}

Regarding to the whole discussions, the conclusion of this study is that the student in the accelerated class has more scientific literacy skills in terms of scientific reasoning and problem solving, than the student who attend regular class. Moreover, the student of acceleration program has funcional level, but the student of regular program has nominal level. It means that the scientific literacy of both students are still low. Then, it can be suggested that students should be familiarized with scientific literacy tests, scientific literacy books and taught with learning models that can train scientific literacy skills.

\section{ACKNOWLEDGMENT}

I would like to express my sincere gratitude to Universitas Muhammadiyah Sidoarjo for its support to publish this paper.

\section{REFERENCES}

[1] Deboer, George E. Scientific literacy: Another look at its historical and contemporary meanings and its relationship to science education reform. Journal of research in science teaching, 2000, 37.6: $582-601$.

[2] Tatum, B. Charles. Accelerated Education: Learning on the Fast Track. Journal of Research in Innovative Teaching, 2010, 3.1.

[3] Permendikbud tentang Penyelenggaraan Sistem Kredit Semester Pada Pendidikan Dasar Dan Pendidikan Menengah., 2014.

[4] Ballenger, C. Social identities, moral narratives, and scientific argumentation: Science talk in a bilingual classroom. Language and Education, 1997, 11, 1-13.

[5] Bazerman, C. Shaping written knowledge: The genre and activity of the experimental article in science. Madison, WI: University of Wisconsin Press. 1988.

[6] Germann, P., \& Aram, R. Student performances on the science processes of recording data, analyzing data, drawing conclusions, and providing evidence. Journal of Research in Science Teaching, 1996, 33, 773- 798.

[7] Nkpolu-Oroworukwo, Port Harcourt. Improving Scientific Literacy among Secondary School Students through Integration of Information and Communication Technology. 2011.

[8] Cmec. Assessment Framework.Canada : Council of Ministers of Education. 2016

[9] Okada, Alexandra. Scientific Literacy in the digital age: tools, environments and resources for co-inquiry. European Scientific Journal, ESJ, 2014, 9.10

[10] Shofiyah, Noly. Deskripsi Literasi Sains Awal Mahasiswa Pendidikan IPA Pada Konsep IPA. PEDAGOGIA: Jurnal Pendidikan, 2015, 4.2: 113-120.

[11] Odja, Abdul H.; Payu, Citron S. Analisis kemampuan awal literasi sains siswa pada konsep IPA. In: Prosiding Seminar Nasional Kimia. 2014.

[12] Soobard, Regina; Rannikmae, Mia. Assessing Student's Level of Scientific Literacy Using Interdisciplinary Scenarios. Science Education International, 2011, 22.2: 133-144.

[13] Sargeant, Joan. Qualitative research part II: Participants, analysis, and quality assurance. 2012.

[14] Turner III, Daniel W. Qualitative interview design: A practical guide for novice investigators. The qualitative report, 2010, 15.3: 754.

[15] Rusilowati, A.; Sunyoto, E. N.; Mulyani, S. E. S. Developing of Science Textbook Based on Scientific Literacy For Seventh Grade Of Secondary School. In: International Conference on Mathematics, Science, and Education (ICME). 2015.

[16] Setyaningrum, Vidhy Andika. Pengembangan Model Pembelajaran Science, Environment, Technology, and Society (SETS) Dilengkapi Collaborative Mind Mapping untuk Memberdayakan Literasi Lingkungan pada Materi Pencemaran. 2016. PhD Thesis. Universitas Sebelas Maret.

[17] Bybee, Rodger W. Achieving scientific literacy: From purposes to practices. Heinemann, 88 Post Road West, PO Box 5007, Westport, CT 06881, 1997.

[18] Al-Rsa'i, Mohammed Salameh. Promoting scientific literacy by using ICT in science teaching. International Education Studies, 2013, 6.9: 175.

[19] Brickman, Peggy, et al. Media-savvy scientific literacy: Developing critical evaluation skills by investigating scientific claims. The american biology Teacher, 2012, 74.6: 374-379. 